\title{
Correction to: Development and modelling of realistic retrofitted Nature-based Solution scenarios to reduce flood occurrence at the catchment scale
}

\author{
Valerie Chen, Jose Ricardo Bonilla Brenes, Fernando Chapa, \\ Jochen Hack iD
}

Published online: 5 March 2021

\section{Correction to: Ambio}

https://doi.org/10.1007/s13280-020-01493-8

In the original publication, the affiliation of all the authors were mixed up and processed incorrectly. It has been updated in this correction.

The original article has been corrected.

Open Access This article is licensed under a Creative Commons Attribution 4.0 International License, which permits use, sharing, adaptation, distribution and reproduction in any medium or format, as long as you give appropriate credit to the original author(s) and the source, provide a link to the Creative Commons licence, and indicate if changes were made. The images or other third party material in this article are included in the article's Creative Commons licence, unless indicated otherwise in a credit line to the material. If material is not included in the article's Creative Commons licence and your intended use is not permitted by statutory regulation or exceeds the permitted use, you will need to obtain permission directly from the copyright holder. To view a copy of this licence, visit http://creativecommons. org/licenses/by/4.0/.

Publisher's Note Springer Nature remains neutral with regard to jurisdictional claims in published maps and institutional affiliations.
Valerie Chen

Address: Department of Civil and Environmental Engineering, Technical University Darmstadt, Franziska-Braun-Str. 7, 64287 Darmstadt, Germany.

Jose Ricardo Bonilla Brenes

Address: Research Group SEE-URBAN-WATER, Section of Ecological Engineering, Institute of Applied Geosciences, Technical University Darmstadt, Schnittspahnstr. 9, 64287 Darmstadt, Germany.

Fernando Chapa

Address: Research Group SEE-URBAN-WATER, Section of Ecological Engineering, Institute of Applied Geosciences, Technical University Darmstadt, Schnittspahnstr. 9, 64287 Darmstadt, Germany.

Jochen Hack ( $\square)$

Address: Research Group SEE-URBAN-WATER, Section of Ecological Engineering, Institute of Applied Geosciences, Technical University Darmstadt, Schnittspahnstr. 9, 64287 Darmstadt, Germany. e-mail: contact@geo.tu-darmstadt.de

The original article can be found online at https://doi.org/10.1007/ s13280-020-01493-8. 